\title{
Age, Growth and Demographic Structures of Thorny Flathead Rogadius asper, Cuvier, 1829 (Pieces: Platycephalidae) from the Coastal Waters of the Suez Gulf
}

\author{
Manal Sabrah, Amal Amin, Aly El Sayed \\ Fisheries Department - Fisheries Biology Lab. National Institute of Oceanography and Fisheries, Niof, Egypt
}

Email address:

manal_sabrah@yahoo.co.uk (M. Sabrah),aminamal30@yahoo.com (A. Amin), aly_el_sayed@yohoo.com (A. E. sayed)

To cite this article:

Manal Sabrah, Amal Amin, Aly El Sayed. Age, Growth and Demographic Structures of Thorny Flathead Rogadius asper, Cuvier, 1829

(Pieces: Platycephalidae) from the Coastal Waters of the Suez Gulf. American Journal of Life Sciences. Special Issue: New Horizons in Basic and Applied Zoological Research. Vol. 3, No. 6-1, 2015, pp. 1-6. doi: 10.11648/j.ajls.s.2015030601.11

\begin{abstract}
The age and growth of the Olive tail Rogadius asper exploited by the demersal trawl fishery in the Gulf of Suez were investigated during the fishing season 2014/2015. Ageing was done by sagittal otoliths for a sample of 675 ranged from 9.2 to $25.9 \mathrm{~cm}$ in total length (TL) with mean of $17.4 \pm 2.95 \mathrm{~cm}$. The sex ratio was skewed in favors of females (1.6:1), which tended to high in number and bigger in size than males. The maximum investigated age of females was 4 years and that of males was 3 years. The mean von Bertalanffy growth parameters for both sexes $\mathrm{L} \infty=26.43 \pm 0.22 \mathrm{~cm}$ and $\mathrm{K}=0.47 \pm 0.03 \mathrm{year}{ }^{-1}$ as estimated by four different methods. According to gender the growth was variable and significantly differed ( $\mathrm{P}<0.05=0.002)$. Females attained a greater mean $\mathrm{L} \infty=27.2 \pm 0.44 \mathrm{~cm}$ than males $\mathrm{L} \infty=24.0 \pm 0.26 \mathrm{~cm}$ and males displayed greater mean $\mathrm{k}$ value $0.53 \pm 0.02$ year $^{-1}$ than that of females $\mathrm{K}=0.43 \pm 0.01$ year $^{-1}$. Fish of age groups 1 and 2 years were dominated the age compositions of $R$. asper constituting $36.6 \%$ and $39.3 \%$ respectively. The estimated value of total mortality, natural mortality and fishing mortality for the pooled data was: $Z=1.51 \pm 0.25,0.58 \pm 0.09$ and $0.93 \pm 0.08$ year $^{-1}$ respectively. It was indicated that the fishing mortality was more than one third (37.6\%) of the derived natural mortality and exploitation rate was 0.62 , indicating that the species was heavily exploited. Although $R$. asper is not a target species of commercial fisheries, it suffers high exploitation as part of the by-catch for its suitable market price for insufficient income.
\end{abstract}

Keywords: Gulf of Suez, Red Sea, Rogadius asper, Age \& Growth, Demographic Structure

\section{Introduction}

According to [1] around 65 species have been described in the family Platycephalidae, is that represent 18 genera. It is distributed in estuarine and coastal waters throughout mainly the Indo-Pacific region. Several of its species are protandrous hermaphrodites [2]. The thorny flathead Rogadius asper is a member of family Platycephalidae, found on sand or mud bottoms of the continental shelf at a depth range of 15-95 $\mathrm{m}$, it is a Marine dweller bottom species [3, 4]. It is well known from Mozambique and Amirantes to the Red Sea, Gulf of Oman, Pakistan, India and Sri Lanka. Also in the Eastern Indian Ocean and the Western Central Pacific to Japan, the Philippines and Australia, caught mainly by bottom trawls [3] and reaching maximum total length of $17.0 \mathrm{~cm}$ [5]. The thorny flathead fish is the most abundant and relatively high occurrence of the trawl by-catch fishery landed at the Gulf of Suez fishing ports. There is no information available on the age, growth and population dynamics of this species, except [6] studied the mode of reproduction in $R$. asper, while the length weight relationship was carried out by [7]. There are some works related other species of the family Platycephalidae in other regions. The population structure and the stock assessment of Platycephilus indicus were reported by [8, 9]. The age compositions, Spawning, maturity and growth of Platycephalus fuscus were investigated by $[10,11]$, and the age \& growth of Platycephalus speculator was devoted by [12].

Despite Rogadius asper catch belong to the trawl bycatch, it is supporting the local commercial markets and became heavily exploited for its suitable price. The present study provides accurate information on the length and age compositions, growth parameters and mortality rates of $R$. asper, these data will be provided knowledge for conserving this species, as it is became closed to overfish. 


\section{Materials and Methods}

This study was carried out between Septembers 2014and April 2015 off the Gulf of Suez. The samples were obtained using commercial bottom trawl vessels. Samples were transferred from the fishing port (Attaka port) to the laboratory, then sorted into groups using length intervals of $1 \mathrm{~cm}$. The sub sampling procedure was applied as recommended by [13]. The total length and total weight for each sample were measured to the nearest $1 \mathrm{~cm}$ and $0.1 \mathrm{gm}$ respectively. Fish was separated into female and male $(\mathrm{F}: \mathrm{M})$ to estimate sex ratio. Chi-square $\left(X^{2}\right)$ test was used to test deviations from the expected sex ratio (1:1). For age determination, sagittal otoliths were extracted from each individual, cleaned, dried and stored in labeled envelope. Otoliths were examined under stereo binocular microscope for estimated age at each length. Agelength keys were formed by obtaining a matrix of numbers at age by length interval for each sample based on all specimens. The model of Age-length key analysis is based on the principles (MULTIFAN 32 program) described by [14; 15]. The length-weight relationships were determined according to the allometric equation given by [16]

$$
\mathrm{W}=\mathrm{a} \mathrm{L}^{\mathrm{b}}
$$

Where, $\mathrm{W}$ is total weight, $\mathrm{a}$ and $\mathrm{b}$ are regression constants and $\mathrm{L}$ is total length. The $\mathrm{b}$ value was tested by t-test to verify that it was significantly different from the isometric growth (b: 3). One-way ANOVA was used to determine difference in length (TL) and body weight between sexes. Growth in length was expressed in terms of von Bertalanffy [17] equation:

$$
\mathrm{Lt}=\mathrm{L} \infty[1-\mathrm{e}-\mathrm{K}(\mathrm{t}-\mathrm{to})]
$$

The growth parameters Lo: asymptotic length and $\mathrm{K}$ : growth rate were estimated by four methods; the Least Squares as recommended by [18], Wetherall [19], ELEFAN I using the appropriate routines in FISATII [20] and SLCA [21]. Value of $t_{0}$ (the hypothetical time at which length is equal to 0 ) was estimated by substituting the $\mathrm{L} \infty$ and $\mathrm{K}$ in the following empirical equation [22]:

$$
\log \left(-\mathrm{t}_{0}\right) \approx=-0.3922-0.2752 \log \mathrm{L} \infty-1.038 \log \mathrm{K}
$$

The growth performance index (ø) was calculated according to the equation of [23]

$$
\dot{\varnothing}=\log \mathrm{K}+2 \log \mathrm{L} \infty
$$

Estimates of the annual instantaneous total mortality rate (Z) were performed using the age-based catch curve method [24]. Instantaneous annual natural mortality rate (M) was estimated using the following four methods: [25], [26], [27] and [28]. Instantaneous annual fishing mortality rate $(F)$ were calculated as the difference between $\mathrm{Z}$ and $\mathrm{M}(\mathrm{F}=\mathrm{Z}-\mathrm{M})$. The value of the average annual exploitation rate (E) was obtained by $E=F / Z$ [16]. Length at first capture was evaluated by the equation [29]

$$
\mathrm{L}_{\mathrm{c}}=\mathrm{L}^{-}-\mathrm{K}\left(\mathrm{L}_{\infty}-\mathrm{L}^{-}\right) / \mathrm{Z}
$$

Where: Lc is the length at first capture, $\mathrm{L}^{-}$is the mean length of fish in the catch sample, $\mathrm{K}$ and $\mathrm{L} \infty$ are parameters of the von Bertalanffy growth equation and $Z$ is the instantaneous total mortality rate. In order to determine the effect of the over exploitation on $R$. asper catch, the length at first maturation $\left(\mathrm{L}_{\mathrm{m}}\right)$ was estimated using [30] equation:

$$
\log \mathrm{L}_{\mathrm{m}}=0.8979 \log \mathrm{L} \infty-0.0782
$$

\section{Results and Discussion}

\subsection{Sex Ratio and Length Structure}

Sex ratio and length structure constitute basic information in assessing reproductive potential and estimating stock size in fish populations. A total of 675 samples of $R$. asper were examined, including 425 (63\%) females and 250 (47\%) males. Sex ratio showed a significant difference from the expected value of 1:1 and was found to be (female: male $=1.6: 1, \chi 2=$ $21.89, p<0.001)$ in favor to females. The variation in sex composition in different length groups was demonstrated in Figure1, it is clear that the two sexes were nearly equivalent at length groups from $9 \mathrm{~cm}$ to $14 \mathrm{~cm}$, which denoted that the sex ratio was equal at the small sizes. Sex ratio could be influence by food availability, [31] reported that when the food is abundant, females would predominate.

Figure 2, shows the length distribution pattern of $R$. asper. It is obvious that the total length of males ranged $9.5-22.8 \mathrm{~cm}$ with a mean $16.3 \pm 4.2 \mathrm{~cm}$ and that of females ranged 9.2-25.9 $\mathrm{cm}$ with a mean of $18.3 \pm 6.1 \mathrm{~cm}$, whereas the mean total length of all samples was $17.4 \pm 2.95 \mathrm{~cm}$. The majority of samples was in length range $15.0-15.9 \mathrm{~cm}$ in males, females and pooled data respectively, it is clear that females predominant the large sizes $>22.0 \mathrm{~cm}$ than males. The variability in length composition may be attributed to that males were more vulnerability to fishing than females or to the disappearance of males during spawning period as a behavioral pattern to be guarding and housing the new recruits or due to the segregation through various seasons of the year [31and 32].

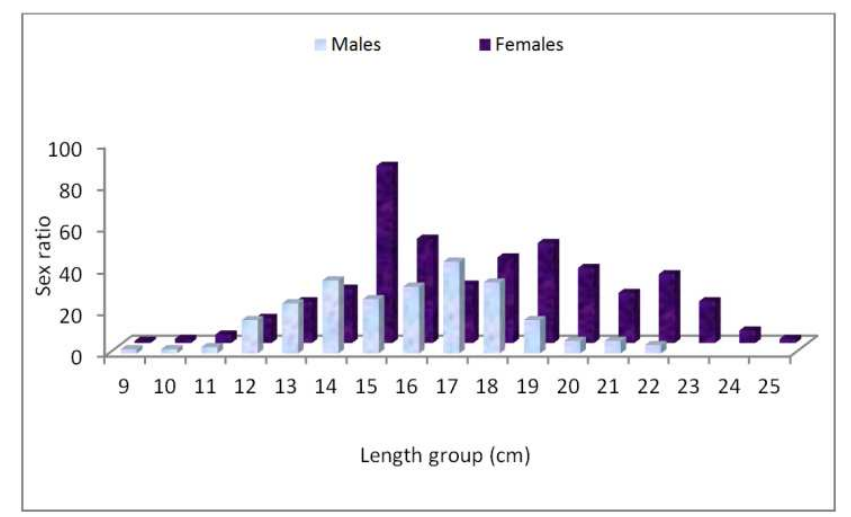

Fig. 1. Variations in sex ratio of $R$. asper according to length groups. 


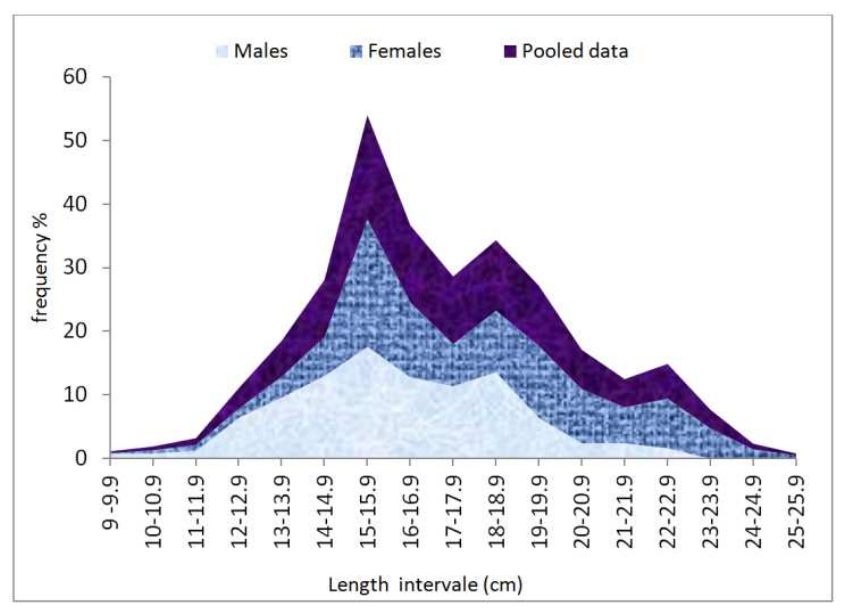

Fig. 2. Overall length structures of R. asper from the Gulf of Suez.

\subsection{Length Weight Relationship}

Length-weight relationship is an important item in the stock assessment models, allow the estimation of biomass and fish condition from the length observations [33]. Statistical relationships between total length and total weight for males, females and pooled samples of $R$. asper are summarized as followed: $\mathrm{W}=0.015 \mathrm{~L}^{2.79}, \mathrm{~W}=0.011 \mathrm{~L}^{2.94}$ and $\mathrm{W}=0.010 \mathrm{~L}^{2.94}$. The $t$-test revealed no significant difference between the allometric coefficient $b$ values and the expected isometric value of 3 ; therefore, neither males $(p=0.226)$ nor females $(p=0.453)$ showed remarkable allometric growth, also there was no significant difference in lengths between sexes $(p=0.633)$, this may be attributed to that large males disappeared or it not be vulnerable to the catch during some periods. A significant difference in both (b) and (a) were observed between sexes (ANCOVA, $p<0.05$ ). No information regarding the length-weight relationship existed for $R$. asper except [7], they reported the length weight relationship as $\mathrm{W}=0.011 \mathrm{~L}^{2.86}$, this result is in agreement with our finding. The length-weight relationship in fishes is affected by number of factors including environmental condition, habitat, food availability, gonad maturity and fish growth rate $[34,35]$.

\subsection{Age Estimation}

Age determination has essential aspects in the fisheries research to evaluate the fish growth, production and its population structure. A total of 675 sagittal otoliths of thorny flathead were examined for fish samples which ranged in length from 9.0 to $25.9 \mathrm{~cm}$. Age determination revealed 5 age groups from 0 to 4 years old. The distribution of samples by age, sex, mean observed lengths \& weights at age and the age composition are shown in (Table 1 and Fig. 3). The results showed that the maximum life span was three and four years for males and females respectively and age group one does the fully recruited one constitute $\approx 40 \%$ of the total examined samples indicating that the most of fish are harvested at one year of age (recruited fish). It is clear that $R$. asper is a short-lived life span constituted maximum age of four years. The observed data showed that, the most rapid growth pattern attained at the first year of life $(15.0 \mathrm{~cm})$, about $43 \%$ of the fish growth to attain the asymptotic length $(\mathrm{L} \infty=26.4 \mathrm{~cm})$ is obtained within the first year of life. It is obvious that male's maximum length were smaller than the females and female gets heavier at high lengths. There was no significant difference was reported in length at age between male and females $(p=0.36>0.05)$. It is the first time to study the age determination of the thorny flathead $R$. asper, there were no knowledge could agree or disagree the present work in the Gulf of Suez.

Table 1. Samples distribution of R. asper by age groups, age composition \%, mean lengths and mean weights at age \pm stander deviation SD.

\begin{tabular}{lllllll}
\hline Males & Fish No. & age group $\%$ & TL $(\mathbf{c m})$ & Mean $\mathbf{L} \pm$ SD & T Wt (gm) & Mean Wt \pm SD \\
\hline Age group & & & $\min$. max. & & min. - max. & \\
0 & 25 & 10.0 & $9.5-13.6$ & $12.4 \pm 1.2$ & $8.3-26.7$ & $17.2 \pm 5.5$ \\
I & 102 & 40.8 & $13.5-18.5$ & $15.3 \pm 1.3$ & $18.3-53.3$ & $33.2 \pm 7.4$ \\
II & 105 & 42.0 & $14.9-22.5$ & $19.0 \pm 1.2$ & $35.4-98.3$ & $52.2 \pm 10.8$ \\
III & 18 & 7.2 & $18.2-22.8$ & $21.2 \pm 1.7$ & $50.7-98.3$ & $74.7 \pm 18.1$ \\
Females & & & & & \\
0 & 35 & 8.2 & $9.2-13.4$ & $11.5 \pm 2.4$ & $8.1-23.5$ & $16.7 \pm 6.6$ \\
I & 145 & 34.1 & $13.6-19.2$ & $15.2 \pm 1.1$ & $14.8-62.2$ & $33.9 \pm 8.9$ \\
II & 160 & 37.7 & $15.7-21.6$ & $19.5 \pm 1.9$ & $21.1-125.7$ & $70.7 \pm 20.3$ \\
III & 70 & 16.5 & $18.6-23.7$ & $22.1 \pm 1.4$ & $37.7-136.9$ & $95.9 \pm 20.7$ \\
IV & 15 & 3.5 & $23.7-25.9$ & $24.0 \pm 0.8$ & $126.5-173.5$ & $141.6 \pm 18.6$ \\
All samples & & & & & & \\
0 & 60 & 8.9 & $9.2-13.6$ & $12.1 \pm 1.3$ & $8.1-26.7$ & $17.1 \pm 6.2$ \\
I & 247 & 36.6 & $13.5-19.2$ & $15.0 \pm 1.2$ & $14.8-62.2$ & $33.5 \pm 8.2$ \\
II & 265 & 39.3 & $14.9-22.5$ & $19.5 \pm 1.83$ & $21.1-125.7$ & $65.8 \pm 17.8$ \\
III & 88 & 13 & $18.2-23.7$ & $22.4 \pm 1.5$ & $35.4-136.9$ & $91.4 \pm 20.4$ \\
IV & 15 & 2.2 & $23.7-25.9$ & $24.0 \pm 0.96$ & $126.5-173.5$ & $141.6 \pm 18.6$ \\
\end{tabular}




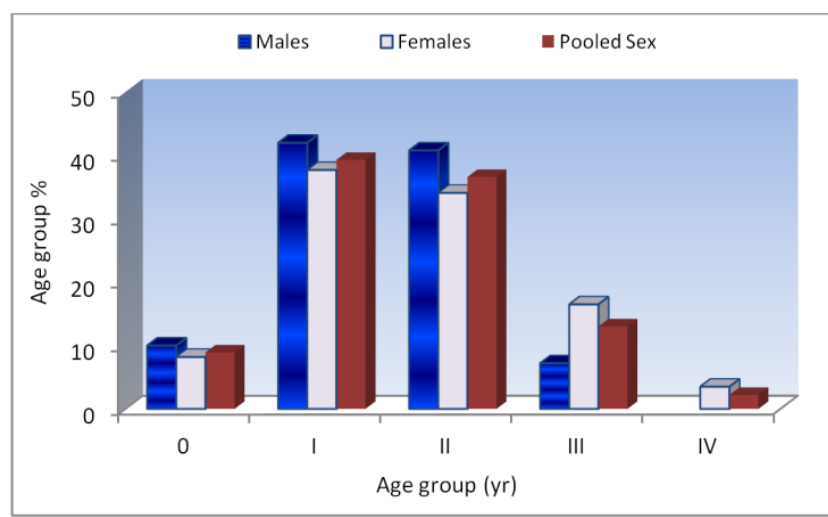

Fig. 3. Percentages of age compositions of R. asper from the Gulf of Suez.

\subsection{Growth Studies}

The asymptotic length $(\mathrm{L} \infty)$, the ratio between the coefficients of total mortality and growth $(\mathrm{Z} / \mathrm{K})$, growth rate $(\mathrm{K})$ and the growth performance (ø) of $R$. asper were estimated by four different methods to show the best result. According to gender the growth was variable and significantly differed $(\mathrm{P}<0.05=0.002)$. Females attained a greater mean $\mathrm{L} \infty=27.2 \pm 0.44 \mathrm{~cm}$ than males $\mathrm{L} \infty=24.0 \pm 0.26$ $\mathrm{cm}$ and males displayed greater mean $\mathrm{k}$ value $0.53 \pm 0.02$ year ${ }^{1}$ than that of females $\mathrm{K}=0.43 \pm 0.01 \mathrm{year}^{-1}$. The estimated Z/k ratio tended to be 2.85 and 3.51 , with mean $\varnothing$ values of 2.48 and 2.50 for males and females respectively.

For the pooled data the obtained results by four different methods to determine the growth parameters of $R$. asper were summarized as in (Table 2). The estimated growth performance index $\varnothing$ values $(2.51,2.54,2.47$ and 2.54 ) were within a very narrow range indicating that all estimates from the four methods confirmed the similarity in the growth pattern of $R$. asper, there was no significant differences were detected in the length-at-age between all methods $(p>0.05)$. It is authorized that all estimated parameters were nearly at the same ranges in all methods with means of $\mathrm{L} \infty=26.43 \mathrm{~cm}, \mathrm{Z} / \mathrm{K}=3.22, \mathrm{~K}=0.47$ year $^{-1}, \mathrm{t}_{0}=$ 0.35 and $\varnothing=2.51$. The von Bertalanffay growth equation of $R$. asper could be written as follow:

$\mathrm{L}_{\mathrm{t}}=26.43\left[1-\mathrm{e}^{-0.47(\mathrm{t}+0.35)}\right]$. The growth parameters resulting from pooled data were used in the subsequent calculations. Results showed that the fish has a relatively slow growth rate $(\mathrm{K})$. There are no available growth data for $R$. asper could be discussed. The growth rate of some species under family Platycephalidae were studied; the estimated $\mathrm{K}=0.7$ year $^{-1}$ for Platycephalus fuscus [36] and $\mathrm{k}=0.5 \mathrm{year}^{-1}$ for $P$. indicus $[34,9]$. The reported growth rates are within the range of that in $R$. asper, despite these species are larger in sizes than $R$. asper.

Table 2. Growth parameter of R. asper (pooled data) estimated by different methods with means \pm stander deviation SD.

\begin{tabular}{llllll}
\hline Parameters & ELEFAN I & Least square & SLCA & Powell-Wetherall & Mean \pm SD \\
\hline L $\infty(\mathrm{cm})$ & 26.30 & 26.70 & 26.30 & 26.50 & $26.43 \pm 0.22$ \\
Z/K & 3.23 & 3.08 & 3.50 & 3.05 & $3.22 \pm 0.21$ \\
$\mathrm{~K}$ yr- & 0.47 & 0.49 & 0.43 & 0.49 & $0.47 \pm 0.03$ \\
t0 $\mathrm{yr}$ & -0.36 & -0.34 & -0.39 & -0.34 & -0.35 \\
$\varnothing$ & 2.51 & 2.54 & 2.47 & 2.54 & $2.51 \pm 0.33$ \\
\hline
\end{tabular}

\subsection{Demographic Structure}

\subsubsection{Age-Length Key (ALK)}

The age-length key was used to estimate the age compositions and average length-at-age of the length frequency. The fish length and age were combined to create an age-length key (ALK). Various methods for construction and evaluation of age-length keys are described in the literature [37]. The application and testing of the theoretical age-length keys is only an indication of the quality and usefulness of the aging method. Table 3, showed the agelength key for pooled samples of $R$. asper. It is evident that age groups I (39.3\%) and II (36.6\%) were the most representative age groups. These two groups take a wide range of lengths from 12.0 to $21.0 \mathrm{~cm}$; beside they comprised together more than $70 \%$ of the total samples (Fig. 3). Average total length-at-age increased from $15 \mathrm{~cm}$ at age group 1 to $24 \mathrm{~cm}$ at age group 4 . The predominance of young fishes suggested that the fishing processes mainly harvesting the under sizes fish and doom the stock, causing the overfishing.
Table 3. Age-Length Key distribution for all samples of R. asper.

\begin{tabular}{|c|c|c|c|c|c|c|}
\hline \multirow{2}{*}{$\begin{array}{l}\text { Length stratum } \\
(\mathrm{cm})\end{array}$} & \multicolumn{6}{|c|}{ Age Groups (Yr.) } \\
\hline & $\mathbf{0}$ & I & II & III & IV & Total \\
\hline $9.0-9.9$ & 2 & & & & & 2 \\
\hline $10.0-10.9$ & 8 & & & & & 8 \\
\hline $11.0-11.9$ & 25 & & & & & 25 \\
\hline $12.0-12.9$ & 20 & 3 & & & & 23 \\
\hline $13.0-13.9$ & 5 & 11 & & & & 16 \\
\hline $14.0-14.9$ & & 60 & & & & 60 \\
\hline $15.0-15.9$ & & 110 & 8 & & & 118 \\
\hline $16.0-16.9$ & & 32 & 31 & & & 63 \\
\hline $17.0-17.9$ & & 25 & 36 & & & 61 \\
\hline $18.0-18.9$ & & 20 & 50 & 2 & & 72 \\
\hline $19.0-19.9$ & & 4 & 90 & 8 & & 102 \\
\hline $20.0-20.9$ & & & 26 & 16 & & 42 \\
\hline $21.0-21.9$ & & & 4 & 23 & & 27 \\
\hline $22.0-22.9$ & & & 2 & 30 & 1 & 33 \\
\hline $23.0-23.9$ & & & & 9 & 5 & 14 \\
\hline $24.0-24.9$ & & & & & 7 & 7 \\
\hline $25.0-25.9$ & & & & & 2 & 2 \\
\hline Total & 60 & 265 & 247 & 88 & 15 & 675 \\
\hline
\end{tabular}

\subsubsection{Instantaneous Annual Mortality and Exploitation} Rates

The total mortality $(Z)$ was estimated by the length converted catch curve method [24] and computed to be 1.51 
$\mathrm{y}^{-1}$ with SE $=0.05$ and $95 \%$ confidence interval (CI) of 1.311.56 and $\mathrm{r}^{2}=0.996$. The natural mortality (M) was calculated by four applied methods: Taylor [25], Cushing [26], Jensen [27] and Hewitt \& Hoenig [28]. The estimated values of natural mortality coefficient (M) were reported in (Table 4).
Natural mortality (M) ranged from 0.5 to $0.7 \mathrm{y}^{-1}$, with an average of $0.58 \pm 0.09 \mathrm{y}^{-1}$ that was used in the subsequent calculations. The fishing mortality $(\mathrm{F})$ was directly estimated to be $0.93 \pm 0.08 \mathrm{y}^{-1}$. The exploitation rate (E) was computed to be 0.62 .

Table 4. Mortality and exploitation rates of R. asper estimated by different methods with means \pm stander deviation $S D$

\begin{tabular}{|c|c|c|c|c|c|}
\hline Parameters & Taylor, 1960 & Cushing, 1968 & Jensen, 1996 & Hewitt \& Hoenig, 2005 & Mean \pm SD \\
\hline Natural mortality rate $(\mathrm{M}) / \mathrm{Yr}$ & 0.50 & 0.50 & 0.70 & 0.60 & $0.58 \pm 0.09$ \\
\hline Total mortality rate $(\mathrm{Z}) / \mathrm{Yr}$ & 1.51 & 1.51 & 1.51 & 1.51 & $1.51 \pm 0.05$ \\
\hline Fishing mortality rate $(\mathrm{F}) / \mathrm{Yr}$ & 1.01 & 1.01 & 0.81 & 0.91 & $0.93 \pm 0.08$ \\
\hline Exploitation ratio $(\mathrm{E})$ & 0.67 & 0.67 & 0.54 & 0.60 & $0.62 \pm 0.06$ \\
\hline
\end{tabular}

\subsubsection{Length at First Capture and at First Maturity}

The length at first capture $\left(\mathrm{L}_{\mathrm{c}}\right)$ which is related to trawl cod end mesh opening was estimated according to the formula of Beverton \& Holt [29], it was found to be $14.5 \mathrm{~cm}$. Wherever, the length at first sexual maturity $\left(\mathrm{L}_{\mathrm{m}}\right)$ was determined according to the equation of Froese \& Binohlan [30] and was found to be $15.8 \mathrm{~cm}$ that coincides nearly age group 1 . No data available on the mortality rates concerning this species, so there was no discussion could be done.

\subsubsection{Brief Summary}

The evaluating of the Rogadius asper population structure revealed that the stock is over-exploited for the main following reasons:

1. The fishing mortality (F) is higher than the natural mortality (M) by $37.6 \%$, whereas Gulland [39, 40] concluded that the yield is optimized when $\mathrm{F}=\mathrm{M}$.

2. $R$. asper exploitation rate (E) was found to be 0.62 ; Gulland [39] suggested that fish stocks are optimally exploited at a level no more than 0.5 . The current level of (E) is higher than the allowable level by about $20 \%$.

3. The length at first capture $\left(L_{c}\right)$ that related to the mesh size is smaller than the length at first maturity $\left(\mathrm{L}_{\mathrm{m}}\right)$ that is implying to that fish is caught before it become mature even for the first time, causing deprivation the fish stock from new generation or new recruitment.

\section{Conclusion}

The thorny flathead, Rogadius asper is the most representative species of the family Platycephalidae in the Gulf of Suez. It constitutes high occurrences of the trawl net by-catch. Thorny flathead gain popularity for its sapid and suitable market price. $R$. asper is a short-lived lifespan, relatively slow growth rate with relatively high rate of natural mortality and high vulnerability to fishing pressure. The present study concluded that, the fishery recourse of this species is heavily overexploited and it should be taking some effective steps to achieve fisheries management proper as: a) regulations of trawl net mesh size. b) reduction in fishing effort. c) closure of the spawning and nursery areas would also be required to protect the spawning stock biomass. d) further studies for getting more information about the Platycephalidae fishery status in the Gulf of Suez.

\section{References}

[1] J.S. Nelson, “ Fishes of The World.” 4th edition. John Wiley and Sons, Inc, New York, (2006), 601pp.

[2] A. Shinomiya, M. Yamada, and T. Sunobe, "Mating system and protandrous sex change in the lizard flathead, Inegocia japonica (Platycephalidae)", (2003). Ichth. Research 50: 383386.

[3] L. W. Knapp, "Platycephalidae. In W. Fischer and G. Bianchi (eds.) FAO species identification sheets for fishery purposes. Western Indian Ocean (Fishing Area 51). (1984), Vol. 3. FAO, Rome. pag. var.

[4] K. Riede, "Global register of migratory species - from global to regional scales" Final Report of the R\&D - Project 80805 081. Federal Agency for Nature Conservation, Bonn, Germany. (2004), 329 p.

[5] G.R. Allen and R. Swainston, "The marine fishes of northwestern Australia: a field guide for anglers and divers". Western Australian Museum, Perth. (1988), 201 p.

[6] C.M. Breder and D.E. Rosen, "Modes of reproduction in fishes". T.F.H. Publications, Neptune City, New Jersey. (1966), $941 \mathrm{p}$.

[7] R., Froese, J. Thorson and R.B. Reyes Jr., "A Bayesian approach for estimating length-weight relationships in fishes". J. Appl. Ichth. (2013):1-7.

[8] H. M. Sabet, A. Heidari and H. Fekrandish," Population structure, length-weight and length-length relationships of six populations of the Bartail Flathead Platycephalus indicus (Scorpaeniformes: Platycephalidae) along the Persian Gulf coastal waters". Journal of Threatened Taxa, January 2015 7(1): 6810-6814.

[9] S. A. Hashemi, S. A. Taghavimotlagh, A. Vahabnezhad, "Stock Assessment of Bartail flathead (Platycephalus indicus Linnaeus, 1758) in northwest of Persian Gulf". Iran. J. Fisheries Sciences, (2014), 8(2): 153-160.

[10] C. A. Gray, V. J. Gale, S. L. Stringfellow and L. P. Raines,"Variations in sex, length and age compositions of commercial catches of Platycephalus fuscus (Pisces: Platycephalidae) in New South Wales, Australia" Marine and Freshwater Research, 2002, 53, 1091-1100.

[11] C. A. Gray and L. M. Barnes, "Spawning, maturity, growth and movement of Platycephalus fuscus (Cuvier, 1829) (Platycephalidae): fishery management considerations" J. Appl. Ichth. (2015), 1-9. 2002. 
[12] G. A. Hyndes, N. R. Loneragan and I. C. Potter, "Influence of sectioning otoliths on marginal increment trends and age and growth estimates for the flathead Platycephalus speculator. Fishery Bulletin, (1992), 90 (2).

[13] M. J. Holden and D. F. S. Raitt, "Manual of Fisheries Science Part 2-Methods of Resource Investigation and their Application”, FAO, Rome, (1974), 214 p.

[14] J. Schnute and D. Fournier, "A new approach to lengthfrequency analysis: growth structure". Can. J. Fish. Aqua. (1980), Sci. 37:1337-1351.

[15] D. A. Fournier, J. R. Sibert, J. Majkowski, and J. Hampton. "MULTIFAN a likelihood-based method for estimating growth-parameters and age composition from multiple length frequency data sets illustrated using data for southern blue fin tuna (Thunnus maccoyii)". Can. J. Fish. Aqua. Sci. (1990), 47:301-317.

[16] P. Sparre and S. C. Venema, "Introduction to tropical fish stock assessment" Part 1. Manual. FAO Fisheries Technical Paper No 306.1. Rev. 2. Rome, FAO, (1998), 407 p. http://www.fao.org/docrep/W5449E/w5449e00.htm.)

[17] L. von. Bertalanffy "A quantitative theory of organic growth (Inquiries on growth laws. 2)” Hum. Biol., (1938) 10:181-213.

[18] M. H. Prager, S. B. Saila and C. W. Recksiek "FISHPARM: A Microcomputer Program for Parameter Estimation of Nonlinear Models in Fishery Science". Old Dominion Univ. Ocean. Tech., Rep. (1989), 87-10.

[19] J. A. Wetherall, J. Polovina and S. Ralston" Estimating growth and mortality in steady-state fish stock from length-frequency data. In: D. Pauly and G.R. Morgan (Eds.), Length-based Methods" in Fishery Research, (1987), 53-74.

[20] F.C. Jr. Gayanilo and D. Pauly, "FAO-ICLARM stock assessment tools. Reference Manual" FAO, Rome. (1997), $262 \mathrm{pp}$.

[21] J.G. Shepherd "A weakly parametric method for estimating growth parameters from length composition data. In: Pauly, D. and Morgan, G. R. (Eds.), Length-based methods" in fisheries research. ICLARM Conf. Proc., (1987), 13: 113-119.

[22] D. Pauly, "Theory and management of tropical multispecies stocks: A review, with emphasis on the Southeast Asian demersal fisheries". ICLARM Studies and Reviews No. 1, 35 p. International Center for Living Aquatic Resources Management, Manila, (1979).

[23] D. Pauly and J. L. Munro "Once more on the comparison of growth in fish and invertebrates". Fishbyte, (1984), 2(1): 21.

[24] W. E. Ricker, "Computation and interpretation of biological statistics of fish populations". Bull Fish Res Bd Can, (1975), $191: 382.4$

[25] C. C. Taylor, "Temperature, growth and mortality: the Pacific cockle". Journal du Conseil, (1960), 26(1): 177-224.
[26] D. H. Cushing "Fisheries biology, a study in population dynamics". University of Wisconsin Press (Madison WN), (1968), $200 \mathrm{p}$

[27] A. L. Jensen "Beverton and Holt life history invariants result from optimal tradeoff of reproduction and survival". Can. J. Fish. Aquat. Sci. (1996), 53, 820-822.

[28] D. A. Hewitt and J. M. Hoenig. "Comparison of two approaches for estimating natural mortality based on longevity. U.S. National Marine Fisheries Service Fishery Bulletin, (2005), 103:433-437.

[29] R. J. Beverton and S. J. Holt. "On the Dynamics of Exploited Fish Populations". Chapman \& Hall, New York, (1957).

[30] R. Froese and C. Binohlan. "Empirical relationships to estimate asymptotic length, length at first maturity, and length at maximum yield per recruit in fishes, with a simple method to evaluate length frequency data". Journal of Fish Biology, (2000), 56:758-773.

[31] G. V. Nikolsky. "The ecology of fishes". 6. ed. London, Academic Press, (1963), 353p.

[32] S. Smith "Life history of lake herring of Green Bay, Lake Michigan”. Fish. Bull. No. 109, Vol. 57, U. S. Fish. \& Wildl. Serv., (1956), 138p.

[33] C. Binohlan, R. Froese and D. Pauly "The length-length table. In: Froese, R.; Pauly, D. (eds). Fishbase 1998: concepts, design and data sources. ICLARM, Manila, (1998), pp. 124.

[34] M. H. Sabet, S. Khataminejad and S. Vatandoust "Length weight and length-length relations of the seven endemic Alburnus species (Actinopterygii: Cypriniformes: Cyprinidae) in Iran". Acta Ichthyologica Et Piscatoria, (2014), 44(2): 157158.

[35] W. F. Tesch, "Age and growth. In: Methods for assessment of fish production in fresh waters". W. E. Ricker (Ed). Blackwell Scientific Publications, Oxford, (1971), pp. 98-130.

[36] C. A. Gray and L. M. Barnes "Spawning, maturity, growth and movement of Platycephalus fuscus (Cuvier, 1829) (Platycephalidae): fishery management considerations. J. Appl. Ichth. (2015), 1-9.

[37] B. Hayes. "A statistical method for evaluating differences between age-length keys with application to Georges Bank haddock, Melanogrammus aeglefinus". Fish. Bull.(1993), 91:550-557

[38] J. A. Musick. "Criteria to define extinction risk in marine fishes". Fisheries, (1999), 24(12): 6-14.

[39] J. A. Gulland "The fish resources of the ocean. West by fleet survey. Fishing News books Ltd., for FAO: 255 p. revised edition of FAO Fish. Tech. pap. (1971), (97):425p.

[40] J. A. Gulland. "Report of FAO/IOP workshop on the fishery resources of the western Indian Ocean South of the Equator". Rome, FAO, IOFC/DEV/1979/45: 1-37. 